\title{
PENGARUH PERILAKU INTERPERSONAL GURU TERHADAP MINAT BELAJAR MATEMATIKA SISWA KELAS X SMA ANGKASA 1 JAKARTA
}

\author{
Ratna Dyah Suryaratri* \\ Helmy Putra** \\ *Universitas Negeri Jakarta \\ ** Universitas Negeri Jakarta
}

DOI: https://doi.org/10.21009/JPPP.071.01

Alamat Korespondensi:

suryaratri@unj.ac.id

\begin{abstract}
This research aims to investigate the influence of interpersonal behavior of teacher on learning interest of Angkasa 1 Senior High School Students in 10th grade. The research method is quantitative using the Likert Scale. Thereby, researchers used the instruments, that have been adapted, the Interpersonal Behavior of Teacher. The literatures used are "Questionnaire on Teacher Interaction" which was written by Wubbels, Creton, and Holvast and modified/edited by Maulana, and "Minat Belajar Matematika" which was written by Fahrul Usman and Fitriani. There are totally 100 Angkasa 1 Senior High School's students in the 10th grade between the ages of 15 and 17 as the samples of this research, which are collected by using the sampling insidental as a method. The method of data processing used for the hypothesis is regression analysis. The result is impressive, the 'higher' interpersonal behavior the teacher shows, the more learning interest on Mathematics the students have. After all, it shows statistically that the learning interest on mathematics is $26 \%$ influenced by the interpersonal behavior of teacher and the rest $74 \%$ by another factors.
\end{abstract}

\section{Keywords}

Interpersonal behavior, teachers, learning interest, mathematics

\section{Pendahuluan}

Menurut Purwanto, "belajar adalah proses yang menimbulkan terjadinya perubahan dalam tingkah laku atau kecakapan. Sampai di mana perubahan itu dapat tercapai, berhasil atau tidaknya belajar, tergantung kepada bermacammacam faktor, diantaranya yaitu guru dan cara mengajarnya". Dalam belajar di sekolah, guru dan cara mengajarnya merupakan faktor yang penting. Sikap dan kepribadian guru, tinggi rendahnya pengetahuan yang dimiliki guru, dan cara guru mengajarkan pengetahuan kepada siswa turut menentukan bagaimana hasil belajar yang dapat dicapai (Purwanto, 2011, dalam Maulidina, 2016).

Bagi guru, mengajar tidak hanya menyampaikan materi pembelajaran tapi juga merupakan proses mengatur lingkungan yang memungkinkan siswa betah dan merasa senang belajar sehingga mereka dapat berkembang secara optimal sesuai dengan bakat, minat, dan potensi yang dimilikinya (Sanjaya, 2008, dalam Maulidina, 2016). Hal ini senada dengan pandangan (Van Petergem, dkk. 2005) yang mengemukakan bahwa pada beberapa kasus terdapat guru yang lebih menyukai lingkungan disiplin untuk belajar, sedangkan beberapa yang lain ingin menciptakan suasana kelas yang menyenangkan, dimana siswa dapat merasa aman untuk mengambil risiko dan menjadi kreatif.

Salah satu fakta terkait rendahnya mutu pendidikan di Indonesia adalah realitas pada rendahnya mutu pendidikan. Terkait dengan 
laporan dari Human Development Report (2015) dipublikasikan berdasarkan laporan Human Development Report, dinyatakan bahwa angka buta huruf dewasa (adult illiteracy rate) di Indonesia mencapai $6,1 \%$. Ini berarti, dari setiap 100 orang Indonesia dewasa yang berusia 15 tahun ke atas, ada 7 orang yang tidak bisa membaca. Angka ini relatif jauh lebih tinggi, apabila kita bandingkan dengan negara-negara lain, seperti Filipina $(3,7 \%)$, Thailand $(3,3 \%)$, dan singapura $(3,2 \%)$. (http://hdr.undp.org)

Sejalan dengan fakta di atas, melaporkan mengenai kondisi HDI (Human Development Indeks) di Indonesia. Dalam laporan tersebut, HDI Indonesia berada pada urutan ke 113 dari 194 negara. Posisi ini masih jauh dari negara-negara tetangga, seperti Malaysia yang menempati urutan ke-59, Brunei Darussalam yang menempati urutan ke 30 dan Singapura yang menempati urutan ke-5. Dibandingkan data yang ada pada tahun 2009, Indonesia mengalami kenaikan jumlah persentase yang cukup membaik. Jika pada tahun 2009 indonesia memiliki jumlah persentase sebesar $8 \%$ yang berarti dari 100 orang dewasa yang berusia 15 tahun ke atas, ada 8 orang yang tidak bisa membaca, dan saat ini Indonesia memiliki jumlah persentase di angka 6,1\%. (http://hdr.undp.org).

Hubungan guru dan siswa dipahami sebagai interaksi interpersonal yang terjadi antara guru dengan siswa yang mengikat mereka satu sama lain. Hubungan ini diasumsikan berasal dari bentuk interaksi tersebut. Pendekatan terhadap hubungan interpersonal guru dan siswa dikonseptualisasikan melalui pengaturan kelas berdasarkan level perilaku interpersonal guru (Wubbels, dkk. 2015).

Hubungan guru dan siswa dapat dipelajari melalui dua kerangka teori yaitu teori interpersonal (Wubbels dkk. 1985) dan kerangka berbasis teori pelengkap (Pianta, 2001). Teori interpersonal mendeskripsikan persepsi dari perilaku guru dengan siswa yang berhubungan dan berinteraksi dalam sebuah sistem. Dalam teori ini, hubungan guru dan siswa digolongkan berdasarkan kombinasi dari dua dimensi, yaitu dimensi pengaruh (influence) dan kedekatan (proximity) dalam Model Perilaku Interpersonal Guru atau Model of Interpersonal Teacher
Behaviour (MITB). Pada kerangka berbasis teori pelengkap yang dipopulerkan oleh Pianta (2001), hubungan guru dan siswa dapat diketahui dengan menggunakan tiga dimensi, yaitu kedekatan (closeness), konflik (conflict), dan kepercayaan (dependency) (Wubbels, dkk. 2015).

Dalam MITB yang dikembangkan oleh Wubbels, dkk (1985), yang merupakan hasil adaptasi dari model Interpersonal Diagnosis of Personality di dalam kelas yang dikembangkan oleh Leary (1957), perilaku guru dipetakan menjadi dua dimensi yaitu dimensi pengaruh (influence) dan dimensi kedekatan (proximity) (Maulana, dkk. 2012). Dimensi pengaruh (influence) memiliki dua sumbu yaitu dominance (D) dan submission (S). Dimensi kedekatan (proximity) memiliki dua sumbu yaitu cooperation (C) dan opposition (O). Dimensi pengaruh (influence) menggambarkan orang yang mengontrol atau mengarahkan proses komunikasi dan seberapa sering hal itu terjadi di kelas. Sedangkan, dimensi kedekatan (proximity) menunjukkan tingkat kerja sama atau kedekatan di antara guru-siswa yang terlibat dalam proses pembelajaran di kelas (Goh, 2004, dalam Maulidina, 2016).

Kedua sistem dimensi koordinat tersebut kemudian dibagi menjadi delapan skala perilaku interpersonal guru, yaitu perilaku kepemimpinan (leadership behaviour) (DC), perilaku membantu/bersahabat (helping/friendly behaviour) (CD), perilaku pengertian (understanding behaviour) (CS), perilaku memberi tanggung jawab/kebebasan siswa (student responsibility/freedom behaviour) (SC), perilaku ragu-ragu (uncertain behaviour) (SO), perilaku tidak puas (dissatisfied behaviour) (OS), perilaku menegur (admonishing behaviour) (OD) dan perilaku disiplin (strict behaviour) (DO) (Maulana, dkk. 2011, dalam Maulidina, 2016). Slameto (1988) menyatakan minat besar pengaruhnya terhadap belajar karena bila bahan pelajaran yang dipelajari tidak sesuai dengan minat siswa maka siswa tidak akan belajar dengan sebaik-baiknya karena tidak ada daya tarik baginya (Slameto, 1988: 57).

Siswa akan terdorong untuk belajar manakala mereka memiliki minat untuk belajar. Oleh sebab 
itu, mengembangkan minat belajar siswa merupakan salah satu teknik dalam mengembangkan motivasi belajar dan salah satu cara untuk membangkitkan minat belajar siswa dengan menghubungkan bahan pelajaran yang akan diajarkan dengan kebutuhan siswa. Wina Sanjaya (2011, dalam Usman, 2016) mengatakan minat siswa akan tumbuh manakala ia dapat menangkap bahwa materi pelajaran itu berguna untuk kehidupannya. Guru perlu menjelaskan keterkaitan materi pelajaran dengan kebutuhan siswa.

Salah satu prestasi belajar yang penting diperhatikan adalah prestasi belajar matematika, karena penguasaan matematika bagi siswa akan menjadi sasaran ampuh untuk mempelajari mata pelajaran lain baik pada jenjang pendidikan sekolah dasar maupun pada jenjang pendidikan yang lebih tinggi. Matematika merupakan dasar yang melandasi semua disiplin ilmu, baik ilmu eksakta maupun ilmu sosial sehingga matematika menjadi tujuan yang aktual dalam setiap perubahan masyarakat dan dunia pendidikan (Nawang Sari, 2001).

Menurut Ginsburg (1983), matematika merupakan salah satu mata pelajaran yang memperoleh perhatian khusus dalam dunia pendidikan, khususnya pendidikan dasar, dimana siswa diajak mengenal, memahami, serta mahir dalam menggunakan bilangan dalam kaitannya dengan praktik kehidupan sehari-hari. Kemampuan matematika pada anak dapat dijadikan dasar untuk memudahkan, menerima pelajaran lain, mengembangkan kemampuan berkomunikasi dengan menggunakan bilangan dan simbol, mempertajam penalaran yang dapat memperjelas permasalahan dalam kehidupan sehari-hari, menguasai materi kejenjang berikutnya dan menumbuhkan kemampuan melakukan analisis. Melalui pendidikan matematika seseorang siswa diharapkan mampu dan terampil dalam melakukan penalaran serta berpikir kritis, logis, dan sistematis deduktif serta dapat memperlakukan objek empiris secara abstrak (Sudjiono, 2003).

Berdasarkan hasil wawancara dengan guru matematika SMA Angkasa 1, hasil belajar siswa pada mata pelajaran matematika belum stabil, kadang tinggi kadang rendah dan rata-rata nilai kelas $x$ adalah 6,75. Oleh karena itu, perlu dilakukan perbaikan pembelajaran yang tepat agar nilai tetap stabil. Selanjutnya, berdasarkan hasil wawancara dengan siswa tentang perilaku guru matematika yang mengajar mereka di kelas, guru matematika mengajar dengan perilaku yang cenderung positif, contohnya guru menunjukkan sikap yang bersahabat dengan para siswanya, namun terkadang mereka menuturkan guru cenderung membosankan dengan cara mengajar yang diberikan kepada para siswanya

\section{Perilaku Interpersonal Guru}

Menurut (Wubbels, dkk. 2015) pendekatan terhadap hubungan interpersonal guru dan siswa dikonseptualisasikan melalui pengaturan kelas berdasarkan level perilaku interpersonal guru.

Model Perilaku Interpersonal Guru didasarkan pada penelitian Timothy Leary tentang diagnosa kepribadian interpersonal dan aplikasinya terhadap pengajaran. Dalam model ini, perilaku guru dipetakan menjadi dua dimensi, yaitu dimensi Influence (Pengaruh) memiliki dua sumbu, yaitu Dominance (D) dan Submission (S). Dimensi Proximity (kedekatan) memiliki dua sumbu, yaitu Opposition (O) dan Cooperation (Wubbels \& Brekelmans, 2005).

\section{Dimensi Influence}

(pengaruh)

menggambarkan siapa yang mengontrol atau mengarahkan proses komunikasi dan seberapa sering hal itu terjadi. Sedangkan dimensi Proximity (Kedekatan) menunjukkan tingkat kerjasama atau kedekatan di antara mereka yang terlibat dalam proses komunikasi. Kedua dimensi Influence (Pengaruh) dan Proximity (Kedekatan) secara bebas mengingatkan pada perilaku guru yang efektif yang dapat mempengaruhi proses pembelajaran di kelas. Masing-masing dari dua sumbu dimensi DS dan CO mewakili perilaku yang berlawanan, sumbu DS untuk dominasi (dominance) dan kepatuhan (submission) dan sumbu CO untuk kerjasama (cooperation) dan oposisi (opposition) (Goh, 1994).

Setiap kuadran dari struktur koordinat yang dihasilkan berdasarkan dua dimensi menampilkan dua segmen dari perilaku guru. Sektor yang ada didefinisikan bergantung pada 
derajat dari perilaku yang ditentukan. Sebagai contoh, kuadran pertama terdiri atas dua karakter yang berbeda yang disebut DominanceCooperation (DC) dan Cooperation-Dominance (CD). DC menunjukkan perilaku guru yang terkarakterisasi dengan tingginya tingkat dominasi dan sedikit kerjasama. Sedangkan CD menampilkan perilaku guru dengan yang dikarakteristikan dengan tingginya tingkat dominasi dan sedikit kerja sama. Sedangkan CD menampilkan perilaku guru dengan tingginya tingkat kerja sama dan tingkat dominasi yang lebih sedikit. Selanjutnya, tiap kuadran dari model ini terdiri atas dua sektor perilaku yang digambarkan pertama kali dari perilaku yang paling umum dan kemudian diikuti oleh perilaku kedua dari dimensi yang sama (Maulana, dkk. 2012).

Kedua sistem dimensi koordinat tersebut kemudian dibagi menjadi delapan skala perilaku interpersonal guru-siswa, yaitu perilaku kepemimpinan (leadership behavior) (DC), perilaku membantu/bersahabat (helping/friendly behavior) (CD), perilaku pengertian (understanding behavior) (CS), perilaku memberi tanggung jawab/kebebasan siswa (student responsibility/freedom behavior) (SC), perilaku ragu-ragu (uncertain behavior) (SO), perilaku tidak puas (dissatisfied behavior) (OS), perilaku menegur (admonishing behavior) (OD) dan perilaku disiplin (strict behavior) (DO) (Maulana, dkk. 2012).

\section{Minat Belajar Matematika}

Slameto (1988) menyatakan minat besar pengaruhnya terhadap belajar karena bila bahan pelajaran yang dipelajari tidak sesuai dengan minat siswa maka siswa tidak akan belajar dengan sebaik-baiknya karena tidak ada daya tarik baginya. Menurut Slameto indikator minat belajar terdiri dari perbuatan, perhatian, dan perasaan senang.

\section{Partisipasi-Perbuatan}

Minat yang telah muncul, diikuti oleh tercurahnya perhatian pada kegiatan belajar mengajar dengan sendirinya telah membawa murid ke suasana partisipasi aktif dalam kegiatan belajar mengajar. Kegiatan berpartisipasi aktif tidak selalu berupa gerakan-gerakan badaniah.
Murid-murid yang ikut aktif secara aqliyah atau secara batinniyah dalam proses pengajaran. Sementara itu, minat tidak timbul secara tiba-tiba atau spontan melainkan timbul akibat dari partisipasi. Jadi, jelas bahwa soal minat akan selalu berkait dengan soal kebutuhan atau keinginan. Oleh karena itu, yang penting bagaimana menciptakan kondisi tertentu agar siswa selalu aktif dan ingin terus belajar.

\section{Perhatian}

Perhatian akan lebih besar bila pada siswa ada minat dan bakat. Bakat telah dibawa siswa sejak lahir, namun dapat berkembang karena pengaruh pendidikan dan lingkungan. Perhatian dapat berarti sama dengan konsentrasi, dapat pula minat momentan, yaitu perasaan tertarik pada suatu masalah yang sedang dipelajari. Konsentrasi dalam belajar dipengaruhi oleh perasaan siswa dalam minatnya terhadap belajar. Siswa yang merasa tidak senang dalam belajar dan tidak berminat dalam materi pelajaran akan mengalami kesulitan dalam memusatkan tenaga dan energinya. Sebaliknya siswa yang merasa senang dan berminat akan mudah berkonsentrasi dalam belajar. Senada dengan pendapat di atas menyatakan bahwa perhatian adalah konsentrasi atau aktivitas jiwa kita terhadap pengamatan, pengertian, dan sebagainya.

\section{Perasaan}

Perasaan adalah suatu pernyataan jiwa yang sedikit banyak bersifat subjektif untuk merasakan senang atau tidak senang dan tidak bergantung pada perangsang dan alat-alat indra. Sementara itu, perasaan adalah keadaan atau state individu sebagai akibat dari persepsi terhadap stimulus baik eksternal maupun internal. Perasaan di sini adalah perasaan momentan dan intensional. Momentan berarti bahwa perasaan pada saat-saat tertentu, intensional yang berarti bahwa reaksi perasaan diberikan terhadap sesuatu, seseorang atau situasi tertentu. Apabila situasi berubah maka perasan berganti pula sehingga perasaan momentan dan intensional dapat digolongkan ke dalam perasaan tidak senang antara minat dan merasa senang terdapat hubungan timbal balik sehingga tidak mengherankan kalau siswa yang merasa tidak senang juga akan kurang berminat dan sebaliknya. Beberapa ahli pendidikan 
berpendapat bahwa cara yang paling efektif untuk membangkitkan minat belajar pada suatu subyek yang baru adalah dengan menggunakan minatminat siswa yang telah ada. Misalnya siswa menaruh minat pada olahraga balap mobil. Sebelum mengajarkan percepatan gerak, pengajar dapat menarik perhatian siswa dengan menceritakan sedikit mengenai balap mobil yang baru saja berlangsung kemudian sedikit demi sedikit diarahkan ke materi pelajaran yang sesungguhnya.

\section{Metode Penelitian}

Tipe penelitian yang digunakan pada penelitian ini adalah kuantitatif. Metode ini sebagai metode ilmiah karena telah memenuhi kaidah-kaidah ilmiah yaitu konkret/empiris, obyektif, terukur, rasional, dan sistematis. Melalui klasifikasi tersebut pengambilan data yang dilakukan oleh peneliti menggunakan metode penelitian berdasarkan tingkat kealamiahan dengan metode survey karena tidak adanya pengkondisian pada subjek penelitian.

Populasi dalam penelitian ini adalah siswa kelas X di SMA Angkasa 1 Jakarta yang berusia 15 - 17. Dalam penelitian ini, teknik pengambilan sampel yang digunakan adalah non probability sampling jenis Sampling Insidental. Untuk menentukan jumlah sampel dari populasi penelitian, peneliti menggunakan penentuan jumlah sampel yang dikemukakan oleh Slovin, rumus perhitungan jumlah sampel dijabarkan dibawah ini:

$$
\begin{aligned}
n & =\frac{600}{1+600(0.1)^{2}} \\
& =85,71=86
\end{aligned}
$$

Berdasarkan perhitungan yang telah dilakukan dengan rumus Slovin, maka sampel yang digunakan dalam penelitian ini berjumlah 100 orang. Teknik pengumpulan data yang digunakan pada penelitian ini adalah teknik survei dengan menggunakan kuesioner untuk siswa dan wawancara tidak terstruktur untuk guru dan siswa.

Alat ukur perilaku interpersonal guru yang peneliti gunakan dalam penelitian ini adalah QTI (Questionnaire on Teacher Interaction) yang disusun oleh Wubbels, Creton, dan Holvast (1998) dengan konstruk yang modifikasi oleh
(Maulana, dkk. 2011). Instrumen perilaku interpersonal guru terdiri dari 52 item dengan 37 item favorable dan 15 item unfavorable. Pada penelitian ini menggunakan skala likert untuk mengukur pengungkapan diri dari jawaban responden. Responden diminta untuk memilih empat alternatif jawaban selalu, sering, kadangkadang, dan tidak pernah. Alat ukur minat belajar matematika yang peneliti gunakan dalam penelitian ini adalah Skala Minat Belajar Matematika yang disusun oleh Fahrul Usman dan Fitriani (2016). Instrumen minat belajar matematika terdiri dari 14 item dengan 6 item favorable dan 8 item unfavorable. Pada penelitian ini menggunakan skala likert untuk mengukur pengungkapan diri dari jawaban responden. Responden diminta untuk memilih empat alternatif jawaban sangat setuju, setuju, tidak setuju, dan sangat tidak setuju.

Uji coba instrumen ini dilakukan pada 70 subjek yang memiliki karakteristik yang sesuai dengan kriteria yang diinginkan oleh peneliti. Uji coba validitas dan reliabilitas menggunakan Winstep 3.73. Reliabilitas merupakan indeks yang menunjukkan seberapa jauh alat ukur dapat dipercaya. Dalam penelitian ini, uji validitas dan reliabilitas instrumen menggunakan pemodelan Rasch.

Tabel 1. Skala Likert Untuk Instrumen Perilaku Interpersonal Guru dan Minat Belajar Matematika Instrumen Jawaban Fav Unfav

\begin{tabular}{llll}
\hline & Tdk Pernah & 1 & 4 \\
\cline { 2 - 3 } $\begin{array}{l}\text { Perilaku } \\
\text { Interpersonal } \\
\text { Guru }\end{array}$ & Kadang-kadang & 2 & 3 \\
\cline { 2 - 4 } & Sering & 3 & 2 \\
\cline { 2 - 4 } & Selalu & 4 & 1 \\
\hline $\begin{array}{l}\text { Minat Belajar } \\
\text { Matematika }\end{array}$ & Sangat Tidak Setuju & 1 & 4 \\
\cline { 2 - 4 } & Setuju & 2 & 3 \\
\cline { 2 - 4 } & Sangat Setuju & 3 & 2 \\
\hline
\end{tabular}

Metode penelitian berisi jenis penelitian, metode penelitian yang digunakan, pedekatan penelitian yang digunakan (kuantitatif/kualitatif), variabel penelitian, jenis data penelitian, responden penelitian (populasi dan sampel), 
teknik pengumpulan data, instrumen penelitian yang digunakan, dan teknik analisis data.

Metode penelitian disajikan menggunakan font Times New Roman 12pts, spasi 1,0.

\section{Hasil Penelitian dan Diskusi}

Sebelum instrumen digunakan untuk pengambilan data final, terlebih dahulu dilakukan proses uji validitas dan reliabilitas. Untuk pengujian validitas pada penelitian ini melalui expert judgment dari salah satu dosen yang ahli terkait penelitian ini. Untuk reliabilitas instrument perilaku interpersonal guru sebesar 0,98 atau dapat dikategorikan kriteria istimewa, sedangkan untuk instrument minat belajar matematika memiliki reliabilitas sebesar 0,98 atau dapat dikategorikan kriteria istimewa. Peneliti membagikan kuesioner langsung kepada siswa SMA Angkasa 1 pada tanggal 29 Mei dan kepada SMA 93 pada tanggal 13 juni untuk diisi sesuai dengan apa yang dialami dan dirasakan oleh siswa tersebut, tetapi khusus unuk siswa SMA 93 responden didapat saat sedang berada diluar kelas. Selanjutnya pada tanggal 20 juni peneliti membagikan kuesioner via google form kepada beberapa siswa SMA kelas $\mathrm{X}$ melalui kontak personal.

Berdasarkan hasil analisis regresi dapat diketahui nilai $\mathrm{F}$ hitung yang diperoleh adalah sebesar 4,036 dengan nilai $F$ tabel (dengan df 8:91) adalah 3,95. Maka F hitung > dari F tabel dan nilai sig $=0,000$ lebih kecil daripada nilai $\alpha=$ 0,05 . Dengan demikian, dapat disimpulkan terdapat pengaruh antara perilaku kepemimpinan, membantu/bersahabat, memahami, tanggung jawab siswa/kebebasan, ragu-ragu, tidak puas, menjengkelkan, dan ketat secara simultan terhadap minat belajar matematika siswa kelas $\mathrm{X}$ SMA Angkasa 1 Jakarta.

\begin{tabular}{lcc}
\multicolumn{3}{c}{ Tabel 2. Kategorisasi Skor } \\
Perilaku Interpersonal Guru \\
\hline Kategori & Frekuensi & Presentase \\
& & $56 \%$ \\
\hline Rendah & 56 & $44 \%$ \\
\hline Tinggi & 44 & $100 \%$ \\
\hline Tottal & 100 & \\
\hline
\end{tabular}

Berdasarkan tabel di atas dapat diketahui bahwa variabel perilaku interpersonal guru memiliki dua kategori skor, yaitu: kategori rendah berjumlah 56 responden atau sebesar $56 \%$ dan tinggi berjumlah 44 responden atau sebesar $44 \%$.

\begin{tabular}{|c|c|c|}
\hline \multicolumn{3}{|c|}{$\begin{array}{c}\text { Tabel 3. Kategorisasi Skor Minat Belaja } \\
\text { Matematika }\end{array}$} \\
\hline Kategori & Frekuensi & Presentase \\
\hline Rendah & 40 & $40 \%$ \\
\hline Tinggi & 60 & $60 \%$ \\
\hline Tottal & 100 & $100 \%$ \\
\hline
\end{tabular}

Berdasarkan tabel di atas dapat diketahui bahwa variabel minat belajar matematika memiliki dua kategori skor, yaitu: kategori rendah berjumlah 40 responden atau sebesar $40 \%$ dan tinggi berjumlah 60 responden atau sebesar $60 \%$.

Tabel 4. Koefisien Model Summary

\begin{tabular}{cccc}
\hline R & R Square & $\begin{array}{c}\text { Adjust } \\
\text { RSquare }\end{array}$ & $\begin{array}{c}\text { Std. Error } \\
\text { of the } \\
\text { Estimate }\end{array}$ \\
\hline $\mathbf{0 , 5 2 1 2}$ & 0,262 & 0,197 & 0,94092 \\
\hline
\end{tabular}

Tabel tersebut menampilkan perhitungan indeks korelasi ganda (R) sebesar 0,512 dan $\mathrm{R}$ square sebesar 0,262 . Oleh karena hanya ada dua variabel maka besarnya indeks korelasi (r) dan korelasi ganda (R) sama. Melalui tabel ini juga diperoleh nilai $\mathrm{R}$ Square yang menunjukkan seberapa bagus model regresi yang dibentuk oleh interaksi variabel bebas dan variabel terikat. Nilai R Square 0,262 dapat diinterpretasikan bahwa variabel perilaku interpersonal guru memiliki pengaruh kontribusi sebesar 26\% terhadap variabel minat belajar matematika sedangkan sisanya $74 \%$ lainnya dipengaruhi oleh faktorfaktor diluar variabel perilaku interpersonal guru. 
Tabel 3 . Koefisien Model Summary Dimensi Perilaku Interpersonal Guru

\begin{tabular}{|c|c|c|c|}
\hline Dimensi & $\mathbf{R}$ & $\begin{array}{c}\text { R } \\
\text { Square }\end{array}$ & $\begin{array}{c}\text { Adjus } \\
\text { t R }\end{array}$ \\
\hline $\begin{array}{c}\text { Perilaku } \\
\text { kepemimpinan }\end{array}$ & 0,192 & 0,037 & 0,027 \\
\hline $\begin{array}{c}\text { Perilaku } \\
\text { Membantu/ } \\
\text { Bersahabat }\end{array}$ & 0,462 & 0,213 & 0,205 \\
\hline $\begin{array}{c}\text { Perilaku } \\
\text { Memahami }\end{array}$ & 0,350 & 0,122 & 0,113 \\
\hline $\begin{array}{c}\text { Perilaku Ragu- } \\
\text { ragu }\end{array}$ & 0,240 & 0,058 & 0,048 \\
\hline $\begin{array}{c}\text { Perilaku Tidak } \\
\text { Puas }\end{array}$ & 0,397 & 0,157 & 0,149 \\
\hline $\begin{array}{c}\text { Perilaku } \\
\text { Menjengkelkan }\end{array}$ & 0,262 & 0,069 & 0,059 \\
\hline Perilaku Ketat & 0,049 & 0,002 & $-0,008$ \\
\hline
\end{tabular}

Tabel di atas menujukkan nilai koefisien korelasi dari dimensi perilaku kepemimpinan sebesar 0,192 atau $19,2 \%$, perilaku membantu/bersahabat sebesar 0,462 atau $46,2 \%$, perilaku memahami sebesar 0,350 atau $35 \%$, perilaku tanggung jawab/kebebasan sebesar 0,168 atau $16,8 \%$, perilaku ragu-ragu sebesar 0,240 atau $24 \%$, perilaku tidak puas sebesar 0,397 atau $39,7 \%$, perilaku menjengkelkan sebesar 0,262 atau $26,2 \%$, dan perilaku ketat sebesar 0,049 atau $4,9 \%$. Berdasarkan nilai tersebut dapat diinterprestasikan bahwa dimensi perilaku membantu/bersahabat memiliki kontribusi terbesar terhadap variabel minat belajar matematika, yaitu sebesar $46,2 \%$.

Berdasarkan hasil penelitian yang didapat melalui uji analisis regresi dapat ditarik kesimpulan bahwa Ha diterima dan Ho ditolak, artinya terdapat terdapat pengaruh yang signifikan perilaku kepemimpinan, membantu/bersahabat, memahami, tanggung jawab siswa/kebebasan, ragu-ragu, tidak puas, menjengkelkan, ketat secara simultan terhadap minat belajar matematika siswa kelas X SMA Angkasa 1 sebesar $26 \%$ sedangkan sisanya $74 \%$ lainnya dipengaruhi oleh faktor-faktor yang tidak diteliti dalam penelitian ini. Namun dari delapan dimensi perilaku hanya lima dimensi perilaku yang memiliki pengaruh terhadap minat belajar matematika yaitu terdapat pada dimensi perilaku membantu/bersahabat, perilaku memahami, perilaku ragu-ragu, perilaku tidak puas, dan perilaku menjengkelkan. Sedangkan tiga dimensi perilaku lainnya yaitu perilaku kepemimpinan, perilaku tanggung jawab, dan perilaku ketat tidak memiliki pengaruh yang signifikan terhadap minat belajar matematika.

Hasil di atas selaras dengan dimensi perilaku guru yang bekerja sama dan mendominasi tampak berkontribusi pada sikap siswa yang menyenangkan terhadap mata pelajaran, sedangkan perilaku perlawanan dan kepatuhan guru yang memiliki efek sebaliknya (Fisher \& Rickards, 1995). Hal ini juga mengindikasikan bahwa guru matematika di SMA memiliki kecenderungan yang cukup besar untuk membantu siswa termotivasi dalam belajar dan mendapatkan pencapaian hasil belajar yang baik di sekolah karena guru memiliki perilaku interpersonal yang mendukung (Reid \& Fisher, 2008). Hal ini juga berkesinambungan antara pengaruh perilaku guru terhadap minat belajar siswa seperti apa yang diutarakan Slameto (1988) minat besar pengaruhnya terhadap belajar karena bila bahan pelajaran yang dipelajari tidak sesuai dengan minat siswa maka siswa tidak akan belajar dengan sebaik-baiknya karena tidak ada daya tarik baginya. Sehingga secara signifikansi perilaku interpersonal guru berpengaruh terhadap minat belajar matematika. 


\section{Kesimpulan}

Berdasarkan hasil penelitian, dapat dilihat bahwa terdapat pengaruh yang signifikan antara perilaku membantu/bersahabat, tanggung jawab siswa/kebebasan, ragu-ragu, tidak puas, dan ketat/disiplin secara simultan terhadap minat belajar siswa kelas X SMA Angkasa 1 dan pengaruh yang dihasilkan bersifat positif. Artinya semakin tinggi perilaku interpersonal guru pada dimensi membantu/bersahabat, tanggung jawab siswa/kebebasan, ragu-ragu, tidak puas, dan ketat/disiplin secara simultan maka akan semakin tinggi minat belajar siswa kelas X SMA Angkasa 1. Selanjutnya dapat dilihat dilihat bahwa terdapat pengaruh yang signifikan antara perilaku kepemimpinan, memahami, dan menjengkelkan secara simultan terhadap minat belajar matematika siswa kelas X SMA Angkasa 1 dan pengaruh yang dihasilkan bersifat negatif. Artinya semakin tinggi perilaku interpersonal guru pada dimensi kepemimpinan, memahami, dan menjengkelkan secara simultan maka akan semakin rendah minat belajar siswa kelas X SMA Angkasa 1.

\section{Daftar Pustaka}

Ginsburg, H.P. (1983). The Development of Matematical Thinking. New York: Academic Press.

Goh, S. C. (1994). Introducing A Model of Interpersonal Teacher Behaviour. Journal Teaching and Learning Vol. 15 No.1, 30-40.

Human Development Reports. (2015). Diakses pada Mei 27 2015. Tersedia di: http:/hdr.undp.org.

Maulana, R. dkk. (2011). Teacher-Student Interpersonal Relationship in Indonesia: Profiles and Importance to Student Motivation. Asia Pasific Journal of Education, 33-49.

Maulana, R. dkk. (2012). Teacher-Student Interpersonal Relationship in Indonesia Lower Secondary Education: Teacher and Student Perceptions. Learning Environment Research Vol. 15, 251-271.

Maulidina. D. (2016). Analisis Persepsi Siswa Terhadap Hubungan Interpersonal GuruSiswa Pada Pembelajaran Kimia Di Kota
Tanggerang Selatan. (skripsi). Fakultas Ilmu Tarbiyah dan Keguruan Universitas Islam Negeri Syarif Hidayatullah Jakarta. Jakarta. h. 206.

Nawangsari, N.A.F. (2001). Pengaruh SelfAfficacy dan Expentacy Value terhadap kecemasan Menghadapi Matematika. Insan Media Psikologi, 3 ;75-88.

Pianta, Robert C., PhD. (2001). STRS StudentTeacher Relationships Scale Professional Manual. Psychological Assessment Resources, Inc.

Purwanto, N. (2011). Psikologi Pendidikan. Bandung: PT Remaja Rosdakarya.

Rangkuti, A. A. (2012). Konsep dan Teknik Analisis Data Penelitian Kuantitatif Bidang Psikologi dan Pendidikan. Jakarta: FIP Press.

Rangkuti, A. A. (2017). Statistika Inferensial untuk Psikologi \& Pendidikan. Jakarta: Kencana.

Reid, C., \& Fisher, D. (2008). Teacher Interpersonal Behaviour: Its Influence on Student Motivation in Science. Proceedings of the Fifth International Conference on Science, Mathematics and Technology Education Udon Thani, Thailand (pp. 43745). Perth: Key Centre for School Science and Mathematics.

Sanjaya, W. (2008). Strategi Pembelajaran Berorientasi Standar Proses Pendidikan. Jakarta: Kencana Prenada Media Group.

Sanjaya, W. (2008). Strategi Pembelajaran Berorientasi Standar Proses Pendidikan. Jakarta: Kencana Prenada Media Group.

Slameto. (1988). Belajar dan Faktor-faktor yang Mempengaruhinya. Jakarta: Bina Aksara.

Usman. F. \& Fitriani. (2016). Pengaruh Komunikasi Interpersonal Guru Terhadap Minat Belajar Pada Mata Pelajaran Matematika. Journal Seminar Nasional Matematika dan Pendidikan Matematika. 5966.

Van Petergem, K. dkk. (2005). Relationship Between Teacher Characteristics, Interpersonal Teacher Behaviour and Teacher Wellbeing. Journal of Classroom Interaction, 34-43.

Wubbels, T. (1985). Discipline Problems of Beginning Teachers, Interactional Teacher Behaviour Mapped Out. 
Wubbels, T. dkk. (2015). Teacher-Student Relationship and Classroom Management. In E. T. Emmer, \& E. J. Sabornie, Handbook of Classroom Management: Second Edition (pp. 363-386). New York: Routledge.

Wubbels, T., \& Brekelmans, M. (2005). Two

Decades of Research on Teacher-Student Relationship in Class. International Journal of Educational Research Volume 43, 6-24. 